University of Nebraska - Lincoln

DigitalCommons@University of Nebraska - Lincoln

Publications of the US Geological Survey

US Geological Survey

2006

Feral Cats: Too Long a Threat to Hawaiian Wildlife

Steven C. Hess

USGS

Paul C. Banko

USGS

Follow this and additional works at: https://digitalcommons.unl.edu/usgspubs

Hess, Steven C. and Banko, Paul C., "Feral Cats: Too Long a Threat to Hawaiian Wildlife" (2006).

Publications of the US Geological Survey. 112.

https://digitalcommons.unl.edu/usgspubs/112

This Article is brought to you for free and open access by the US Geological Survey at DigitalCommons@University of Nebraska - Lincoln. It has been accepted for inclusion in Publications of the US Geological Survey by an authorized administrator of DigitalCommons@University of Nebraska - Lincoln. 


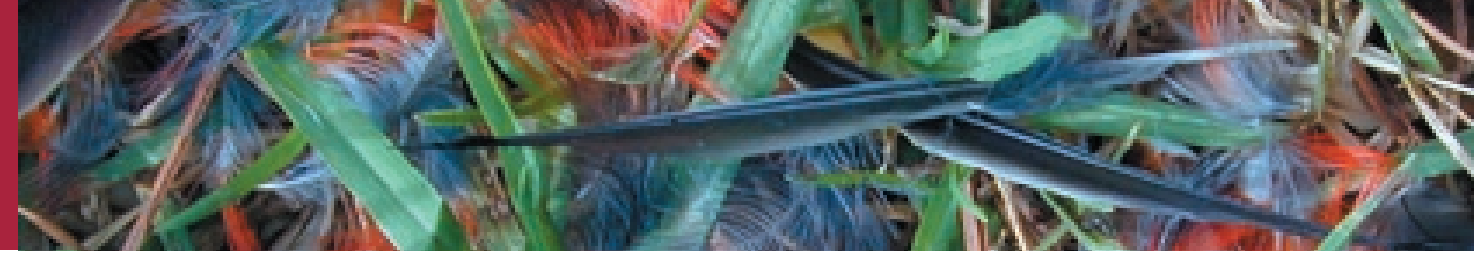

\section{Feral Cats: Too Long a Threat to Hawaiian Wildlife}

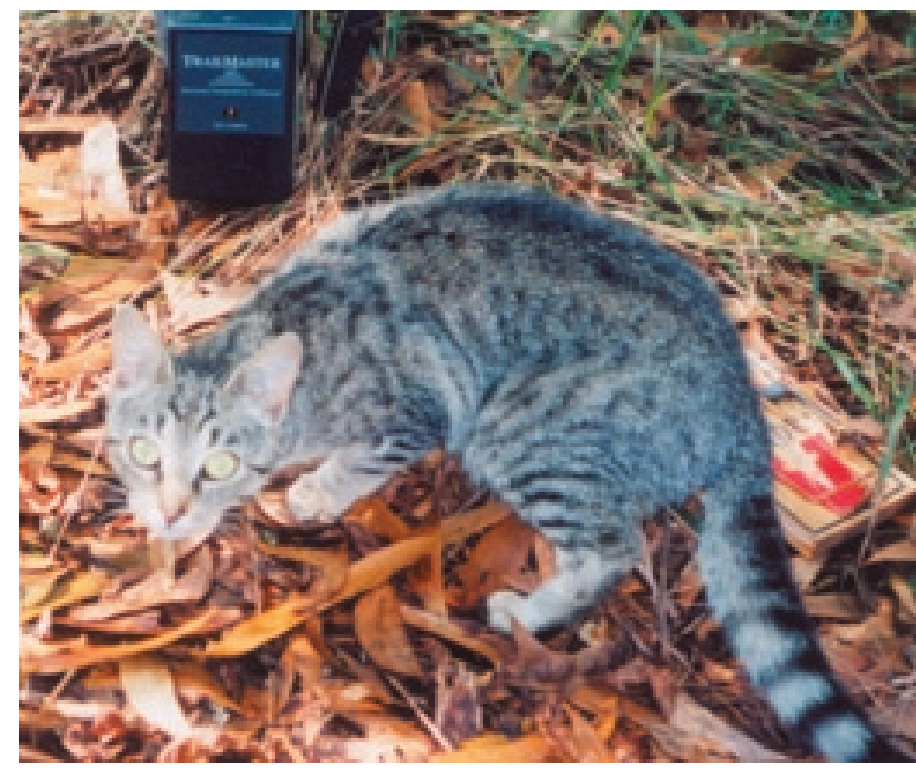

\section{Background}

Domestic cats (Felis catus) were first brought to Hawai' $\mathrm{i}$ aboard sailing ships of European explorers and colonists. The job of these predators was to control mice and rats on the ships during the long voyages. As in other places, cats were taken in and adopted by the families of Hawai' $i$ and soon became household pets known as popoki. But cats have always been very well equipped to live and hunt on their own. On tropical archipelagos like the Hawaiian Islands where no other predatory mammals of comparable size existed, abundant and naïve prey were particularly easy game, and cats soon thrived in the wild.

Although the details of when cats first came to live in the wild remain little known, adventurers, writers, and naturalists of the day recorded some important observations. Feral cats were observed in remote wilderness around Kìlauea volcano on Hawai'i Island as early as 1840 by explorer William Brackenridge. Mark Twain was so impressed by the great abundance of cats when he visited Honolulu in 1866 that he reported his observations in the Sacramento Union newspaper, which were later reprinted in his book Roughing It:

I saw... tame cats, wild cats, singed cats, individual cats, groups of cats, platoons of cats, companies of cats, regiments of cats, armies of cats, multitudes of cats, millions of cats...

\section{Cats Prey on Native Birds in a Variety of Habitats}

Cats were also common in remote and isolated communities, as noted by the famous traveler, Isabella Bird, during her visit to Waimanu Valley on Hawai'i Island in 1873 . By that time, a disturbing but little known phenomenon was beginning to happen to the unique birds of Hawai' $i$. At least 30 species or subspecies
This feral cat was photographed by a remote camera in Hawai'i Volcanoes National Park (see page 3).

of endemic forest birds were either greatly reduced in number or became extinct between 1870 and 1930. One of the earliest naturalists to implicate feral cats as a causal factor in these losses was R.C.L. Perkins, who wrote in 1903:

\begin{abstract}
On Lanai, in walking up a single ravine, I counted the remains of no less than twenty-two native birds killed by cats, and these must all have been destroyed within two days, as previously the whole gulch had been washed out by a heavy flood. Two cats were actually shot on this occasion as they were devouring their prey, and several others seen, but, owing to the fact that they are extremely shy and mostly nocturnal in habits, few people who have not lived much in the woods have any idea of their numbers.
\end{abstract}

In Hawai' $i$ today, cats range from relatively high densities near sea level where abandoned pets are frequently fed by well-meaning animal-lovers, to sparse isolated populations in remote rain forests and even alpine areas on the islands of Maui and Hawai' $i$. Cats kill songbirds, which nest, feed, and roost in trees, and ground nesting birds, such as quail and other introduced game birds. Native sea birds and other species that nest on the ground or in burrows are particularly vulnerable to predation by cats. For example, endangered ' $u a$ ' $u$ (Hawaiian Petrel; Pterodroma sandwichensis) are particularly vulnerable because they raise their single chicks in lava crevices and nestlings cannot fly for more than 15 weeks after hatching. Adult ' $u a^{\text {' }} u$ are also often killed by cats, causing serious population declines because it takes each bird five to six years to reach

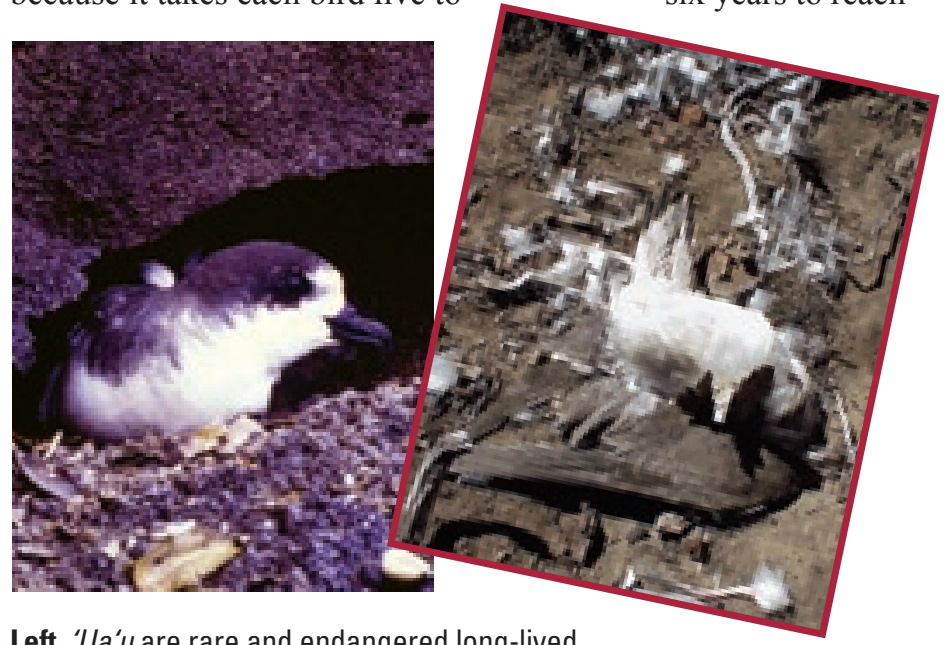

Left. 'Ua'u are rare and endangered long-lived seabirds that feed on fish and squid offshore but nest in lava crevices at high elevation on volcanoes. (Photo by W. Banko) Right. This adult 'ua' $u$ was killed by a cat high on the slopes of Mauna Loa in Hawai'i Volcanoes National Park. (Photo by F. R. Warshauer, USGS) 

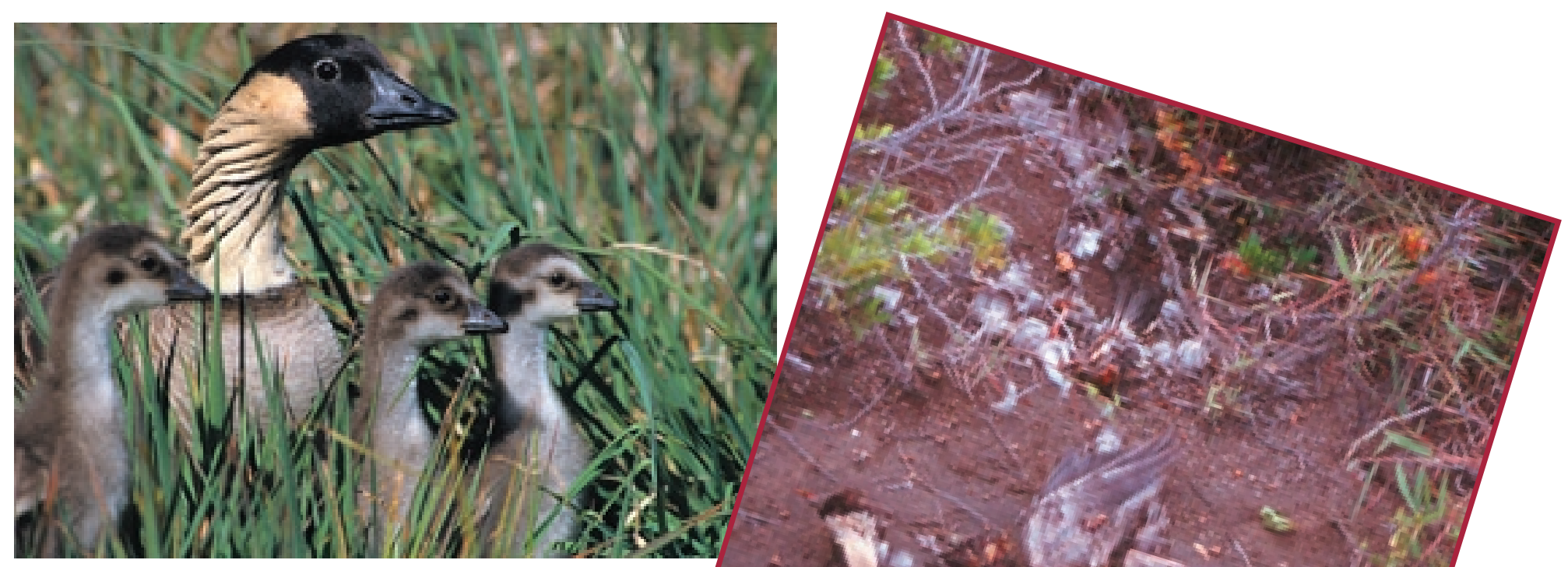

The death of adults has very severe consequences for populations of long-lived birds, because their reproductive rates are low and parental investment in raising young is high. (Photo by J. Jeffrey)

maturity. Even birds that nest and feed in wetlands are killed by cats, demonstrating that no bird in any habitat is safe from these stealthy, wide-ranging, introduced predators.

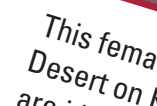

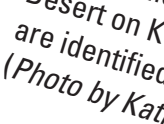

\section{Cats Carry and Transmit Diseases to Other Wildlife}

Not only do cats prey on vulnerable endangered birds, but they also carry diseases that may infect endangered birds and other wildlife. Cats are the definitive host of a potentially fatal disease called toxoplasmosis. In Hawai' $i$, toxoplasmosis has killed native Hawaiian birds such as the critically endangered 'alalā (Corvus hawaiiensis), the endangered nène (Hawaiian goose; Branta sandvicensis), and even seabirds such as the red-footed booby (Sula sula). Because the protozoan organism that causes toxoplasmosis (Toxoplasma gondii) can complete an important part of its life cycle in seawater, this disease also poses a threat to marine mammals. Fatal toxoplasmosis was recently confirmed in an endangered Hawaiian monk seal (Monachus schauinslandi), and may possibly threaten other marine mammals in Hawai 'i such as the spinner dolphin (Stenella longirostris). In addition to threatening wildlife, toxoplasmosis is zoonotic and poses a significant health risk to pregnant women. Feral cats are also known to carry bacteria that have killed pueo (Hawaiian Short-eared Owls; Asio flammeus sandwichensis) and 'alalā.

\section{USGS Studies Ecology of Feral Cats in Subalpine Hawai'i Island}

Feral cats now live throughout the dry subalpine and alpine shrublands of Mauna Kea and Mauna Loa on the island of Hawai ${ }^{\circ}$. Being completely isolated from human settlements, these cats live entirely off the land under extreme conditions, enduring freezing temperatures, battling lethal diseases, and relying entirely on hunting wildlife. Although feral cats exist in small numbers in these rugged ecosystems, they can be very damaging to endangered birds, such as the palila (Loxioides bailleui) and the ' $и a^{\prime} u$. Understanding how feral cats live, move, and feed will allow us to formulate better strategies to protect endangered birds. The USGS has been investigating

\section{feral cats}

using various tools in-

cluding remote cameras and telemetry.

\section{Remote Cameras Capture Images of Feral Cats}

Surveillance cameras installed at nests of the palila revealed that cats reduce palila nest success. Cats mainly kill palila chicks, although adult females may be killed while sitting on the nest. Cat kills at nests not being monitored by cameras are identified by hair, claw marks, and tracks around the nest. Up to $11 \%$ of palila nests are depredated by feral cats each year. These losses may threaten the survival of the species, which lays few eggs each year and takes a long time to develop to adulthood. In contrast, mainland songbirds have much larger clutches and raise nestlings much more quickly, decreasing

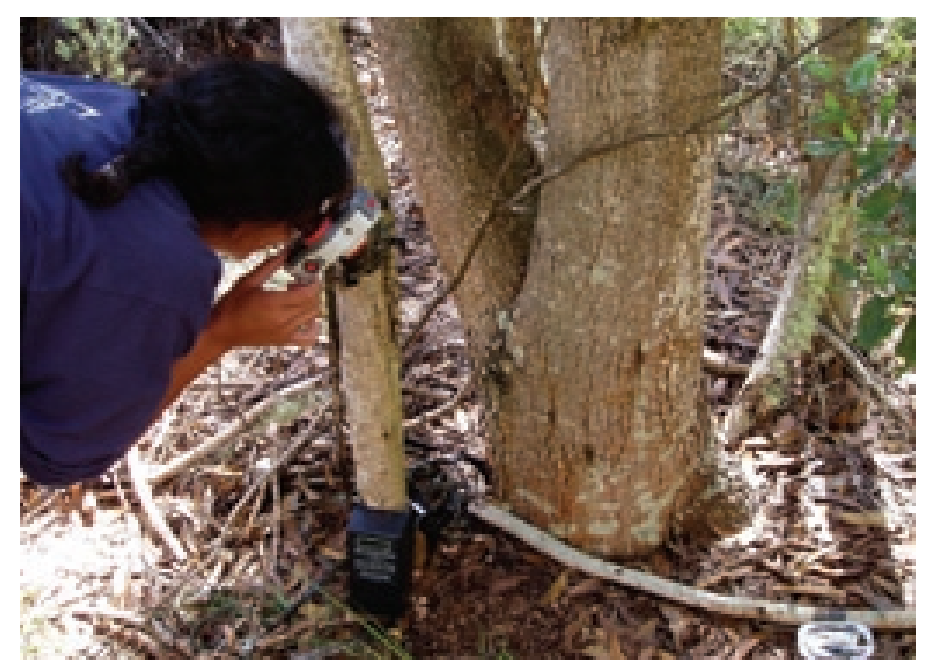

Feral cats are difficult to study because of their nocturnal habits and wariness of people. Infrared-triggered cameras are used to determine the presence of cats in the vicinity of endangered birds. 


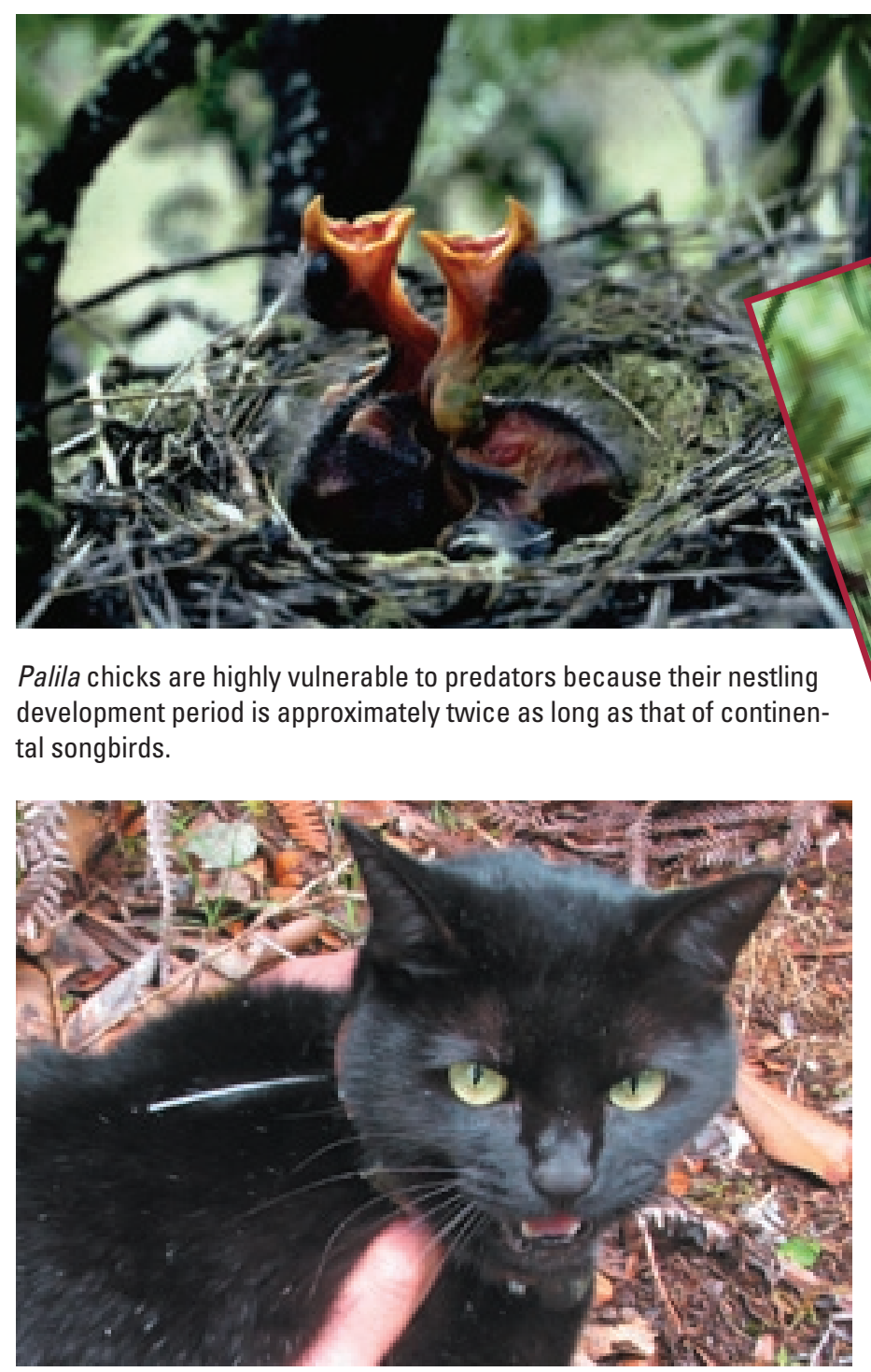

In order to track the movements of feral cats in endangered palila territory, cats were trapped and fitted with radio collars before release back to the wild.

their exposure to predators dramatically. In addition, many Hawaiian birds exhibit little fear of potential predators and often lack avoidance behaviors.

\section{Telemetry}

Radio transmitters were attached to a sample of cats captured on Mauna Kea in order to describe their home ranges, movements and activity patterns. On Mauna Kea, some male cats can range up to 20 $\mathrm{km}^{2}\left(8 \mathrm{mi}^{2}\right)$ and this rivals the largest reported home range for a feral cat from anywhere in the world. In contrast, the home ranges of three females averaged less than $8 \mathrm{~km}^{2}\left(3 \mathrm{mi}^{2}\right)$.

The significance of these large home ranges and daily movements is that cats

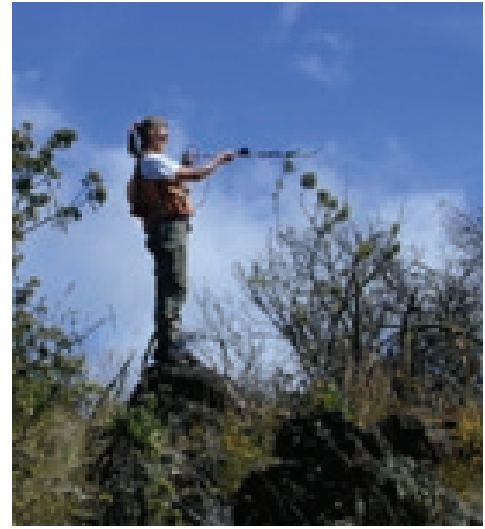

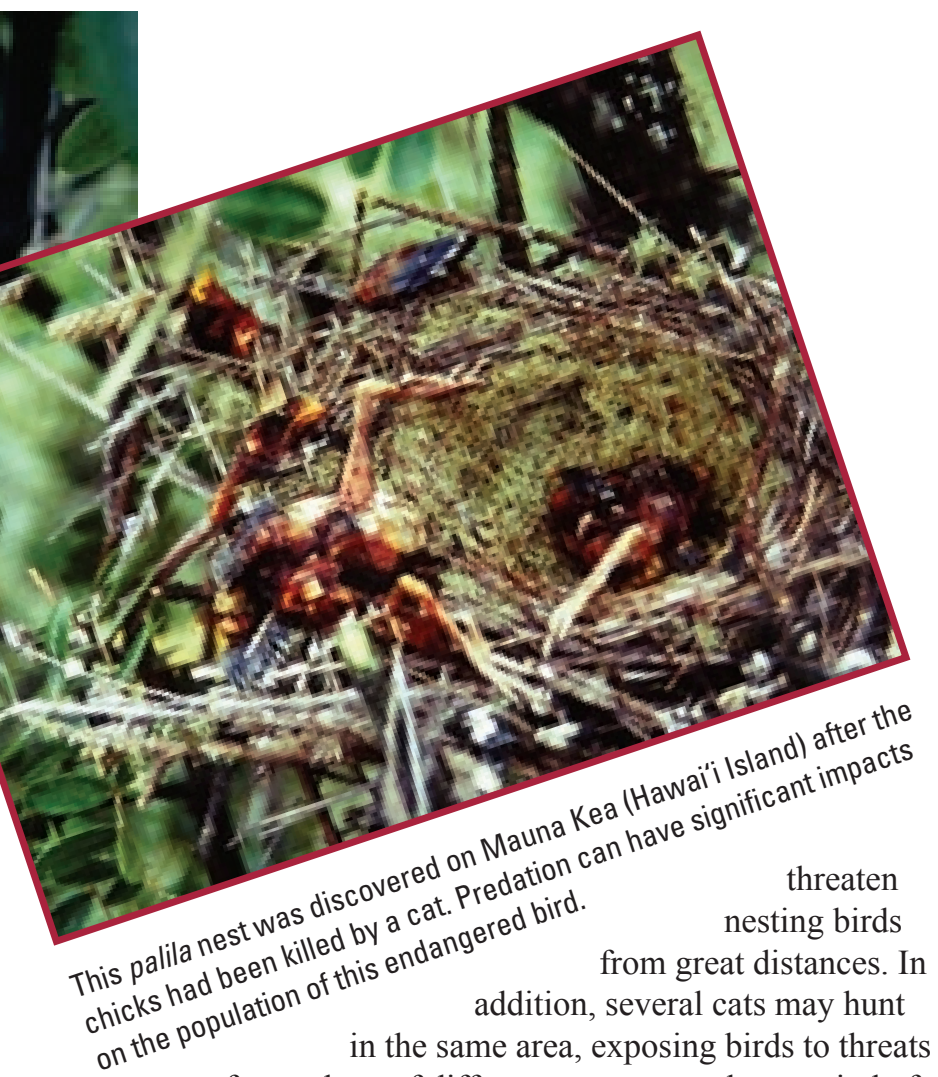

from a host of different cats over a short period of

time. In the case of palila occupying only about $140 \mathrm{~km}^{2}$ $\left(54 \mathrm{mi}^{2}\right)$, the home range of each male cat represents more than $10 \%$ of this area. Cats are most active at night, when birds have settled on their nests and are particularly vulnerable.

\section{Diet}

Stomach contents from feral cats captured at two sites were examined in order to characterize the diet of these introduced predators (Figure 1). Feral cats on Mauna Kea subsist to a great extent on invertebrates and birds, including both songbirds

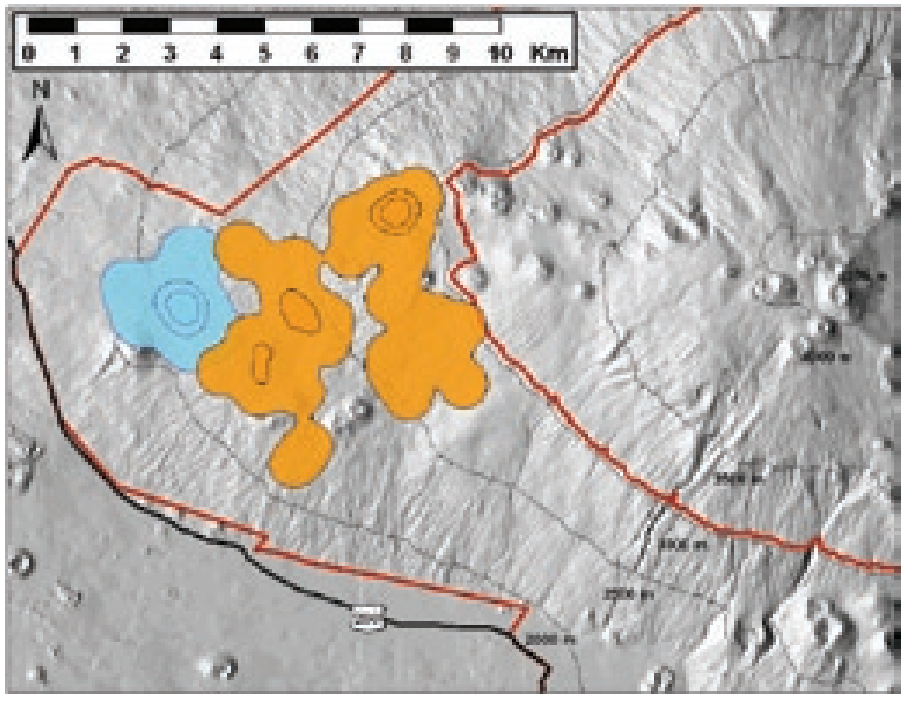

The home ranges of a male (orange) and a female (blue) feral cat within the critical habitat of the endangered palila (red lines) on the West Slope of Mauna Kea. The home range of the male was $20.1 \mathrm{~km}^{2}$, and the home range of the female was $6.1 \mathrm{~km}^{2}$. Smaller shapes inside the home ranges are areas that the cats used more intensively. 


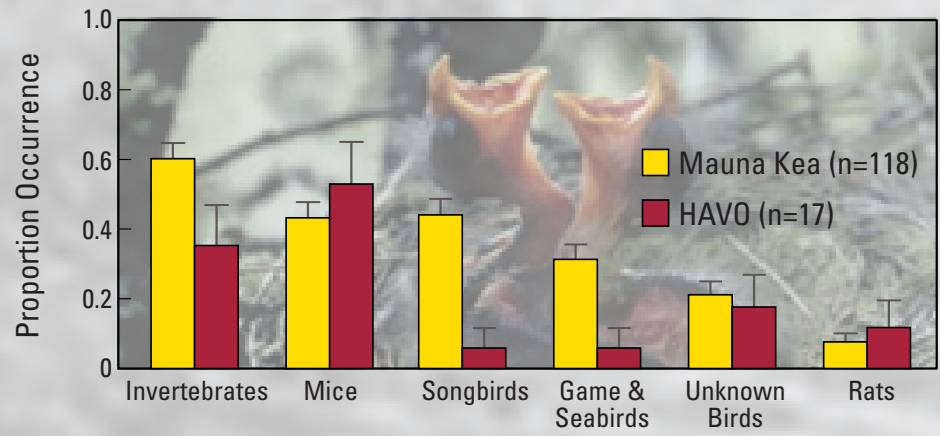

Figure 1. Stomach contents of cats captured at two subalpine sites on Hawai'i Island.

and game birds. Some stomachs contained leg bands from both native and introduced songbirds that had previously been captured and banded at the site. Insects are also common prey items. Surprisingly, rodents are less important than birds and insects despite the great abundance of mice in this environment. In contrast, in Hawai ' $i$ Volcanoes National Park (HAVO), the most common prey items are mice and invertebrates, including grasshoppers and flies. While no gamebirds were found; one stomach contained remains of a young ' $u a^{\prime} u$, identified by a complete mandible set, feathers, and bones. Most of the rodent remains were mice; rats were rarely found. The diet of cats in

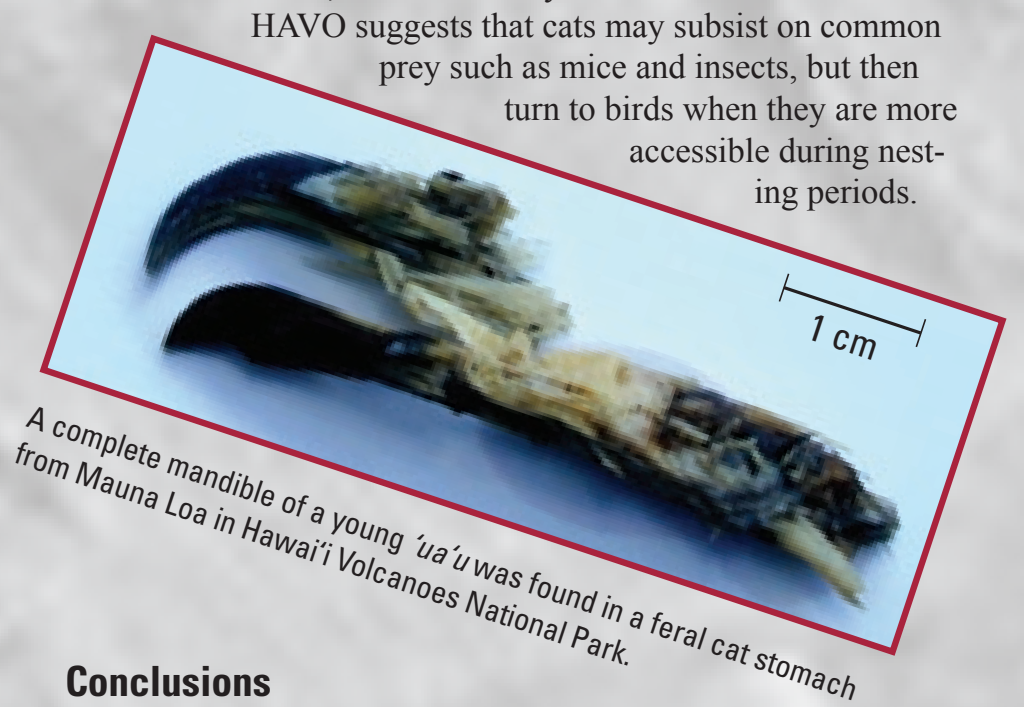

Since their introduction to Hawai' $i$ in the 1800 s, cats have adapted to life on their own in Hawaiian ecosystems, where they are now abundant. Their success in these habitats has been at the expense of native animals, which evolved in the absence of mammalian predators. Native birds are particularly vulnerable. In addition to predation, cats also impact native wildlife by transmitting lethal diseases. For the 'alalā, nēne, palila, and 'ua' $u$, unnatural predation, in addition to other factors, continues to threaten the survival of these endangered species. Given enough time, feral cats may even cause the extirpation of some populations of these birds. USGS is currently collaborating with NPS to reduce the threat of these introduced predators to endangered species in parks throughout Hawai' $i$. These findings will help protect native birds whether they occur in areas managed by USFWS, State of Hawai' $i$, or on privately-owned lands.

\section{What the Public Can Do}

- Be a responsible pet owner by keeping your cat indoors as much as possible, especially at night; keeping track of its whereabouts; and making sure your cat is well-fed at all times.

- Cats that are properly cared-for and kept indoors have been shown to live longer, healthier lives than do feral cats. Please do not release cats into the wild because it is inhumane to both the cats and to the wildlife on which they prey.

- Please help to reduce the population of feral cats by taking them to the Humane Society rather than feeding them. Feeding feral animals only increases their numbers.

- Have your cats spayed or neutered. "If you feed it, fix it."

\section{Suggested Reading}

Banko, P.C. et al. 2002. Availability of food resources, distribution of invasive species, and conservation of a Hawaiian bird along a gradient of elevation. Journal of Biogeography 29: 789-808.

Perkins, R.C.L. 1903. Vertebrata (Aves). Pp. 368-465 in Fauna Hawaiiensis, Vol. I, part IV (D. Sharpe, ed.). The University Press, Cambridge, England.

Simons, T.R., and C.N. Hodges. 1998. Dark-rumped Petrel (Pterodroma phaeopygia). Birds of North America, No. 345. (A. Poole and F. Gill, eds.). The Birds of North America, Inc. Philadelphia, PA.

Tomich, P.Q. 1986. Mammals in Hawaii, 2nd Ed. Bishop Museum Press, Honolulu, HI.

Winter, L. 2003. Popoki and Hawai'i's native birds. 'Elepaio 63: 43-46.

\section{For more information contact:}

Station Leader, Kilauea Field Station Email:PACUC@usgs.gov

\section{Fact sheet written by:}

Steven C. Hess and Paul C. Banko, USGS Pacific Island Ecosystems Research Center

\section{Photo credits:}

Background image this page by Rex Williams. Other photos by USGS, except where noted. 